\title{
Diabetic regulation of subjects with type 2 diabetes mellitus is associated with serum vitamin D levels
}

\author{
DEdip Erkus ${ }^{1}$ \\ iD Gulali Aktas ${ }^{1}$ \\ iD M. Zahid Kocak' \\ (iD) Tuba T. Duman' \\ (iD) Burcin M. Atak ${ }^{1}$ \\ (iD) Haluk Savli ${ }^{1}$
}

1. Abant Izzet Baysal University Hospital, Faculty of Medicine, Department of Internal Medicine, Bolu, Turkey

http://dx.doi.org/10.1590/1806-9282.65.1.51

\begin{abstract}
SUMMARY
OBJECTIVE: Vitamin D deficiency is not only associated with bone metabolism but also with diabetes mellitus. We aimed to study the possible association between serum vitamin D concentration and HbATc level in patients with type 2 diabetes mellitus (T2DM) in this retrospective report.

METHODS: Patients with T2DM were enrolled to the study either in regulated or non-regulated T2DM groups, according to HbA1c levels. An HbA1c level of <8\% was considered as relatively controlled and others were considered as poorly controlled T2DM.

RESULTS: Serum vitamin D levels in poorly controlled T2DM subjects $(9.4(4.9-34) \mathrm{ng} / \mathrm{ml})$ were significantly lower than that of the relatively well regulated T2DM patients $(13.5(3.4-36) \mathrm{ng} / \mathrm{ml})(p=0.03)$. Vitamin D was strongly and inversely correlated with $\mathrm{HbA1c}$ levels $(r=-0.295, p=0.005)$.

CONCLUSION: Whatever the cause or result of the diabetes mellitus, it is clear that lower vitamin $D$ is strongly associated with worse diabetic regulation in T2DM subjects. Randomized controlled larger studies, which research the relation between diabetic regulation and vitamin D status, are needed to claim whether it could be a therapeutic target in future in diabetic subjects.
\end{abstract}

KEY WORDS: Vitamin D. Type 2 diabetes mellitus. Glycated hemoglobin A.

\section{INTRODUCTION}

Type 2 Diabetes Mellitus (T2DM) is a metabolic disorder, which is caused by deterioration in secretion or action of insulin. Prevalence of T2DM has been reached nearly pandemic levels worldwide, in parallel to the increase in obesity.

The role of vitamin $\mathrm{D}$ in many bodily functions has been researched after discovery of vitamin $\mathrm{D}$ receptors in pancreas and immune cells ${ }^{1}$. It has been re- ported that subjects with insufficient vitamin D were prone to develop type 2 diabetes mellitus ${ }^{2}$. Moreover, impaired glucose tolerance has been shown to be meliorated in vitamin D deficient subjects after vitamin D replacement ${ }^{3}$.

Few studies analyzed the possible association between vitamin D serum levels and glycated hemoglobin (HbA1c) in patients with T2DM. Several 
of these reports found an association and others did not. Indeed, vitamin D deficiency could be associated with development of T2DM or diabetic control level. Therefore, we planned a present retrospective study.

\section{OBJECTIVE}

In the present retrospective analysis, we aimed to study the possible association between serum vitamin D concentration and HbA1c level in patients with type 2 diabetes mellitus.

\section{METHODS}

Patients' admissions to outpatient clinics of our institution who have T2DM retrospectively investigated from patient files and computerized database between November 2016 and June 2017. Subjects grouped either into regulated T2DM or into non-regulated T2DM groups, according to HbA1c levels. An HbA1c level of $<8 \%$ was considered as relatively controlled and others were considered as uncontrolled T2DM. Patients with active inflammation, infection, malignancy or chronic kidney disease were excluded from the study. Patients receiving vitamin D supplements were also excluded. Age, gender and other general characteristics, such as height, weight, duration of T2DM and waist circumference were recorded. A body mass index (BMI) was calculated by dividing of the weight in kilograms to the square of height in meters.

Vitamin D levels, serum urea, creatinine, fasting plasma glucose, total, HDL and LDL cholester$\mathrm{ol}$, triglyceride and albumin were obtained from the same database and recorded. HbA1c levels were also obtained and recorded from patient file system. Vitamin $\mathrm{D}$ levels were detected by measuring serum 25-hydroxyvitamin D.

Data were analyzed by SPSS software. (SPSS 15.0; IBM Inc., Chicago, IL, USA). Results expressed as mean \pm SD or median (minimum - maximum). Variables are conducted with independent samples t test or MannWhitney U test. Chi square test used in comparison of categorical variables between study groups. A $p$ value of $<0.05$ is considered as statistically significant. Pearson's correlation analysis test used to reveal possible correlation between vitamin $\mathrm{D}$ and HbA1c levels.

\section{RESULTS}

The study population was consisted of 89 diabetic subjects; 47 in poorly controlled and 42 in relatively

TABLE 1. GENERAL CHARACTERISTICS AND LABORATORY DATA OF STUDY GROUPS

\begin{tabular}{|c|c|c|c|c|}
\hline \multicolumn{3}{|r|}{ Poorly controlled T2DM } & Well-controlled T2DM & $\mathrm{p}$ \\
\hline \multirow[t]{2}{*}{ Gender } & Women (n) & 30 & 20 & \multirow[t]{2}{*}{0.12} \\
\hline & Men (n) & 17 & 22 & \\
\hline \multicolumn{5}{|c|}{ Median (Min.-Max.) } \\
\hline \multicolumn{2}{|c|}{ Age (years) } & $61(40-80)$ & $56.5(29-86)$ & 0.49 \\
\hline \multicolumn{2}{|c|}{ Duration of T2DM (years) } & $10(1-30)$ & $4.5(1-20)$ & 0.02 \\
\hline \multicolumn{2}{|c|}{ Height (m) } & $1.62(1.54-1.83)$ & $1.65(1.45-1.82)$ & 0.40 \\
\hline \multicolumn{2}{|c|}{ Weight (kg) } & $82(60-137)$ & $80(56-120)$ & 0.40 \\
\hline \multicolumn{2}{|c|}{ Waist circumference $(\mathrm{cm})$} & $104(80-141)$ & $100(75-141)$ & 0.33 \\
\hline \multicolumn{2}{|c|}{ Body mass index $\left(\mathrm{kg} / \mathrm{m}^{2}\right)$} & $31.1(22.6-52.2)$ & $29.7(20.6-46.9)$ & 0.22 \\
\hline \multicolumn{2}{|c|}{ Fasting plasma glucose (mg/dl) } & $209(89-422)$ & $126(78-294)$ & $<0.001$ \\
\hline \multicolumn{2}{|c|}{$\operatorname{HbA1c}(\%)$} & $9.7(8-16.6)$ & $6.9(5.4-7.7)$ & $<0.001$ \\
\hline \multicolumn{2}{|c|}{ Vitamin D (ng/ml) } & $9.4(4.9-34)$ & $13.5(3.4-36)$ & 0.03 \\
\hline \multicolumn{2}{|c|}{ Blood urea (mg/dl) } & $30(14-79)$ & $30(17-62)$ & 0.62 \\
\hline \multicolumn{2}{|c|}{ Plasma creatinine (mg/dl) } & $0.83(0.6-1.1)$ & $0.79(0.56-1.1)$ & 0.26 \\
\hline \multicolumn{2}{|c|}{$\mathrm{Na}(\mathrm{mmol} / \mathrm{l})$} & $138(134-145)$ & $139(129-145)$ & 0.24 \\
\hline \multicolumn{2}{|c|}{$\mathrm{K}(\mathrm{mmol} / \mathrm{l})$} & $4.5(3.6-5.3)$ & $4.4(3-5.4)$ & 0.12 \\
\hline \multicolumn{2}{|c|}{ Triglyceride (mg/dl) } & $182(65-841)$ & $149(69-850)$ & 0.03 \\
\hline \multicolumn{2}{|c|}{ Serum albumin (g/dl) } & $4.2(2.5-4.8)$ & $4.3(3.5-4.8)$ & 0.17 \\
\hline \multicolumn{5}{|c|}{ Mean \pm Standard Deviation } \\
\hline \multicolumn{2}{|c|}{ Total cholesterol (mg/dl) } & $194 \pm 51$ & $188 \pm 46$ & 0.53 \\
\hline \multicolumn{2}{|c|}{ HDL cholesterol (mg/dl) } & $46 \pm 10$ & $45 \pm 10$ & 0.53 \\
\hline \multicolumn{2}{|c|}{ LDL cholesterol (mg/dl) } & $127 \pm 31$ & $112 \pm 36$ & 0.04 \\
\hline
\end{tabular}


well-controlled diabetes mellitus groups. Median age of poorly and well-regulated T2DM group was 61 (40$80)$ years and 56.5 (29-86) years, respectively. Age difference was not statistically significant $(\mathrm{p}=0.49)$.

Twenty of 42 subjects in relatively well-controlled T2DM group and 30 of 47 in poorly controlled T2DM group were women. Gender was not statistically different between study groups $(p=0.12)$.

Fasting plasma glucose levels of poorly controlled and well-controlled diabetic subjects were 209 (89422) $\mathrm{mg} / \mathrm{dl}$ and 126 (78-294) $\mathrm{mg} / \mathrm{dl}$, respectively. The difference was statistically significant, as expected $(p<0.001)$. Similarly, HbA1c of poorly controlled diabetics (9.7 [8-16.6] \%) was significantly higher than that of the relatively well-controlled diabetic subjects (6.9 [5.4-7.7] \%), again expectedly ( $<<0.001)$. General characteristics and laboratory data of study population were expressed in table 1.

Body mass index $(\mathrm{p}=0.22)$, waist circumference $(p=0.33)$, blood urea $(p=0.62)$ and creatinine $(p=0.26)$, total $(\mathrm{p}=0.53)$ and HDL $(\mathrm{p}=0.53)$ cholesterol, plasma sodium ( $\mathrm{p}=0.24)$ and potassium $(\mathrm{p}=0.12)$ concentrations, and serum albumin levels $(p=0.17)$ were not significantly different between study groups.

Serum LDL $(p=0.04)$ and triglyceride $(p=0.03)$ were significantly higher in poorly controlled compared to well-controlled diabetic subjects. Duration of T2DM was significantly longer in poorly regulated compared to relatively well-regulated T2DM group ( $\mathrm{p}=0.02)$.

Vitamin D serum levels in poorly and well-regulated T2DM groups were 9.4 (4.9-34) $\mathrm{ng} / \mathrm{ml}$ and 13.5 (3.4-36) $\mathrm{ng} / \mathrm{ml}$, respectively. The difference between study groups was statistically significant $(\mathrm{p}=0.03)$.

Pearson correlation analysis revealed that serum vitamin $D$ was strongly and inversely correlated with HbA1c levels $(r=-0.295, p=0.005)$. Figure 1 shows the correlation between vitamin D and HbA1c (figure 1).

\section{DISCUSSION}

The main finding of the present study is that vitamin D levels were negatively and strongly correlated with HbA1c levels in patients with T2DM. HbA1c reflects blood glucose of the last 3 months and is considered as a marker of diabetic regulation. This negative correlation could be the consequence of vitamin $\mathrm{D}$ being a metabolic biomarker besides its action in bone and calcium metabolism.

Hypovitaminosis of vitamin D have negative effects on both calcium and bone metabolism and diabetes mellitus ${ }^{4}$. Besides its crucial role in calcium and bone metabolism, recent discoveries showed

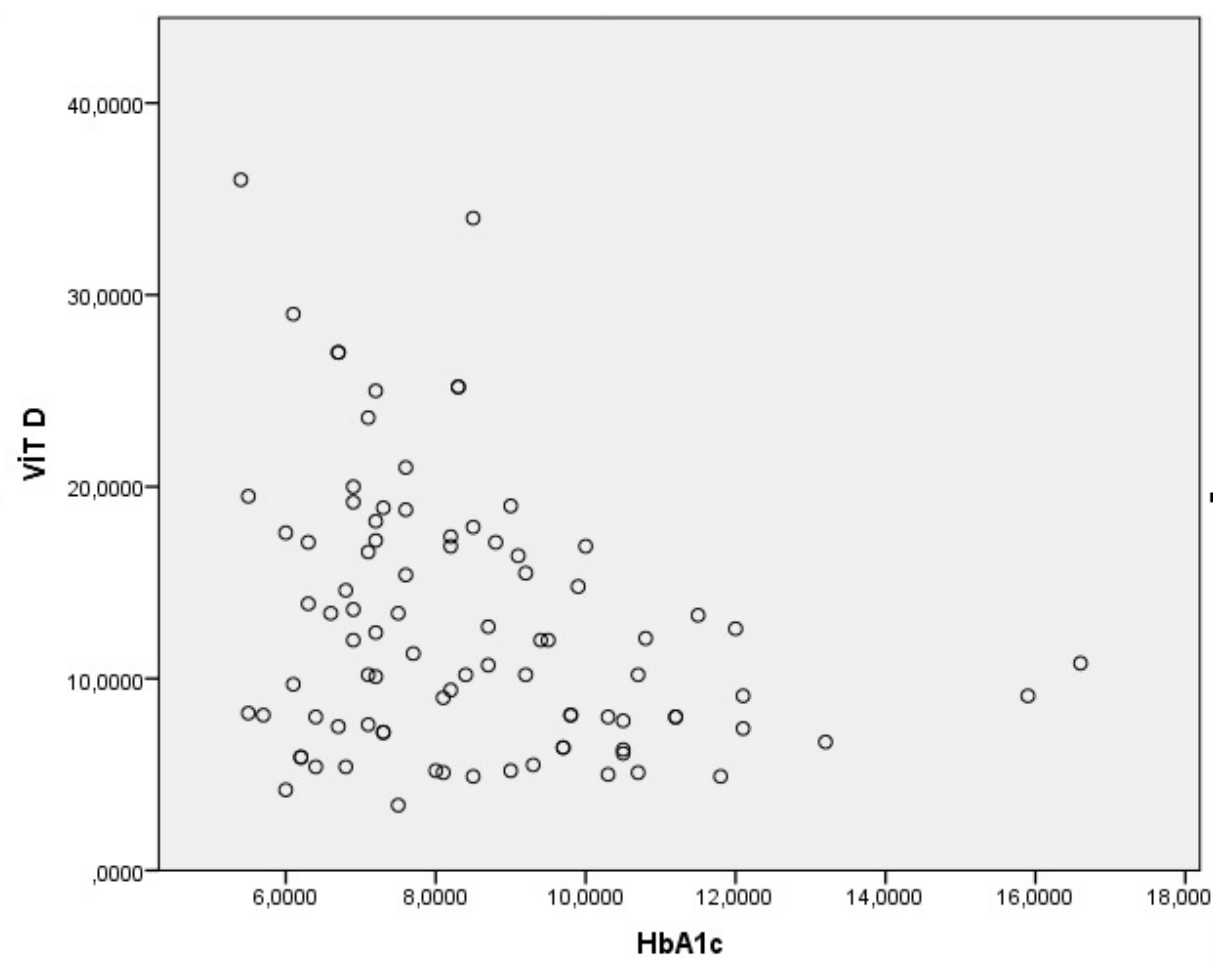


that vitamin D also has important bodily functions. Target tissues of vitamin D include immune cells, heart, stomach, liver, brain, skin, pancreas, thyroid, parathyroid and adrenal glands ${ }^{5}$. Therefore, it is supposed that vitamin D may have inflammatory and immunologic effects. On the other hand, low serum vitamin D is a risk factor not only for diabetes mellitus but also for metabolic syndrome ${ }^{2}$. Another clue of association between T2DM and vitamin D insufficiency could be that obesity increases the incidence of both metabolic syndrome, T2DM and hypovitaminosis $\mathrm{D}^{6}$.

Chiu et al suggested that lower vitamin D status was a risk factor for development of T2DM ${ }^{7}$. In another study, researchers found that vitamin D was more effective than metformin in ameliorating insulin resistance in subjects with metabolic syndrome ${ }^{2}$. Similar results have been reported in literature. Subjects with T2DM had reduced serum vitamin levels compared to healthy population in a study by Scragg et al. ${ }^{8}$. Authors found negative correlations between serum vitamin $\mathrm{D}$ and insulin secretion ${ }^{9}$, and between vitamin D level and prevalence of diabetes ${ }^{10}$.

Results of the studies about the effects of vitamin D in human are conflicting. Repletion of vitamin D in deficient patients caused an increase in insulin production and secretion in T2DM patients ${ }^{11}$. Despite oral vitamin D increased the insulin secretion following oral glucose intake in healthy subjects, its effect was neutral in patients with T2DM ${ }^{2}$. Moreover, deterioration of glycemic control and insulin sensitivity in response to oral vitamin $\mathrm{D}$ has been reported in literature ${ }^{12}$.

We will discuss the possible reasons of the negative correlation between HbA1c and serum vitamin D. Insulin secretion of pancreatic beta cells reduced the vitamin D deficiency. In other words, insulin secretion and normal glucose tolerance is ensured by sufficient amount of vitamin D. Animal studies suggested that vitamin D deficiency lead to both glucose intolerance and even resistance to exogenous insulin ${ }^{13}$. Interestingly, pancreatic insulin secretion increases after vitamin D treatment ${ }^{14,15}$. However, a recent randomized controlled trial revealed that vitamin D supplementation was failed to alter HbA1c levels in patients with type 2 diabetes mellitus ${ }^{16,17}$. Negative correlation between vitamin D and HbA1c levels in this study may support other studies that found association between T2DM and vitamin D status.

Lower vitamin D levels in patients with poor diabetic control compared to better-controlled subjects should be well examined. There are studies that reported vitamin D insufficiency was not the cause but the result of diabetes mellitus. Insulin stimulates production of vitamin $\mathrm{D}$, thus, insulin deficiency or inefficacy as seen in diabetes mellitus may result in a decrease in vitamin $D$ levels ${ }^{5}$.

Retrospective design and small study population are two main limitations of the present report. Nevertheless, the striking negative correlation between serum vitamin D and HbA1c make its results very important.

\section{CONCLUSION}

Either the cause or result, it is clear that lower vitamin $D$ is strongly associated with worse diabetic regulation in T2DM subjects. Randomized controlled larger studies that research the relation between diabetic regulation and vitamin $\mathrm{D}$ status are needed to claim whether it could be a therapeutic target in future in diabetic subjects.

\section{Acknowledgement}

This article has been presented as an abstract in 19th National Internal Medicine Congress in Antalya, Turkey

\section{RESUMO}

CONTEXTO E OBJETIVO: A deficiência de vitamina D não é apenas associada ao metabolismo ósseo, mas também ao diabetes mellitus. Procurou-se estudar a possível associação entre os níveis de concentração do soro de vitamina D e de HbATc em pacientes com diabetes mellitus tipo 2 neste relatório retrospectivo.

MÉTODOS: Os pacientes com diabetes mellitus tipo 2 foram inscritos no estudo em regulada ou não regulada de acordo com os grupos de niveis de HbA1c DM2. HbA1c nivel de <8\% caracterizava DM2 controlada e HbA1c > 8\% DM2 descontrolada.

RESULTADOS: Os níveis de vitamina D no soro em indivíduos com DM2 mal regulados (9,4 (4,9 a 34) ng/ml) foram significativamente menores do que o do bem regulado em doentes DM2 (13,5 (3,4-36) $\mathrm{ng} / \mathrm{ml})(p=0,03)$. A vitamina $D$ foi forte e inversamente correlacionada com os níveis de HbATc ( $p=0,005)$. 
CONCLUSÃo: Seja qual for a causa ou o resultado do diabetes mellitus, é claro que níveis baixos de vitamina D são fortemente associados com pior regulação em indivíduos diabéticos com DM2. Maiores estudos randomizados e controlados que pesquisam a relação entre o status de vitamina D e a regulação em diabéticos são necessários para molusco se é, no futuro, poderia ser um alvo terapêutico em indivíduos diabéticos.

PALAVRAS-CHAVE: Vitamina D. Diabetes mellitus tipo 2. Hemoglobina A glicada.

\section{REFERENCES}

1. Holick MF. Vitamin D: a millenium perspective. Cell Biochem. 2003;88(2):296-307.

2. Chiu KC, Chu A, Go VL, Saad MF. Hypovitaminosis D is associated with insulin resistance and $\beta$ cell dysfunction. Am J Clin Nutr. 2004;79:820-5.

3. Kumar S, Davies M, Zakaria Y, Mawer EB, Gordon C, Olukoga AO, et al. Improvement in glucose tolerance and beta-cell function in a patient with vitamin $D$ deficiency during treatment with vitamin D. Postgrad Med J. 1994;70(824):440-3

4. Mathieu C, Gysemans C, Giulietti A, Bouillon R. Vitamin D and diabetes. Diabetologia. 2005;48(7):1247-57.

5. Bikle DD. Clinical counterpoint: vitamin D: new actions, new analogs, new therapeutic potential. Endocr Rev. 1992;13(4):765-84.

6. Palomer X, González; Clemente JM, Blanco; Vaca F, Mauricio D. Role of vitamin $D$ in the pathogenesis of type 2 diabetes mellitus. Diabetes Obes Metab. 2008;10(3):185-97.

7. Chiu KC, Chuang LM, Yoon $C$. The vitamin D receptor polymorphism in the translation initiation codon is a risk factor for insulin resistance in glucose tolerant Caucasians. BMC Med Genet. 2001;2:2.

8. Scragg R, Holdaway I, Singh V, Metcalf P, Baker J, Dryson E. Serum 25-hy droxyvitamin D3 levels decreased in impaired glucose tolerance and diabetes mellitus. Diabetes Res Clin Pract. 1995;27(3):181-8

9. Baynes KC, Boucher B], Feskens El, Kromhout D. Vitamin D, glucose tol- erance and insulinaemia in elderly men. Diabetologia. 1997;40(3):344-7.

10. Scragg R, Sowers M, Bell C. Serum 25-hydroxyvitamin D, diabetes, and ethnicity in the Third National Health and Nutrition Examination Survey. Diabetes Care. 2004;27(12):2813-8.

11. Borissova AM, Tankova T, Kirilov G, Dakovska L, Kovacheva R. The effect of vitamin D3 on insulin secretion and peripheral insulin sensitivity in type 2 diabetic patients. Int | Clin Pract. 2003;57(4):258-61.

12. Taylor AV, Wise PH. Vitamin D replacement in Asians with diabetes may increase insulin resistance. Postgrad Med J. 1998;74(872):365-6.

13. Ismail $A$, Namala R. Impaired glucose tolerance in vitamin $D$ deficiency can be corrected by calcium. J Nutr Biochem. 2000;11(3):170-5.

14. Boucher $B$ |. Inadequate vitamin D status: does it contribute to the disorders comprising syndrome 'X'? Br J Nutr. 1998;79(4):315-27.

15. Zittermann $A$. Vitamin $D$ in preventive medicine: are we ignoring the evidence? Br | Nutr. 2003;89(5):552-72.

16. Krul-Poel YH, Westra S, ten Boekel E, ter Wee MM, van Schoor NM van Wijland $H$, et al. Effect of vitamin D supplementation on glycemic control in patients with type 2 diabetes (SUNNY trial): a randomized placebo-controlled trial. Diabetes Care. 2015;38(8):1420-6.

17. Garbossa SG, Folli F. Vitamin D, sub-inflammation and insulin resistance. A window on a potential role for the interaction between bone and glucose metabolism. Rev Endocr Metab Disord. 2017;18(2):243-58. 